\title{
ASEAN Maritime Security Cooperation to Combat Piracy within Malacca Strait: A Constructivist Perspective and Extra-Regional Actor's Interests
}

\author{
Raihan Zahirah Mauludy Ridwan \\ Undergraduate Student of International Relations Department at Universitas Katolik Parahyangan \\ raihanzahirahmr@gmail.com
}

\begin{abstract}
Sejalan dengan posisi geografis Asia Tenggara yang strategis untuk rute perdagangan, Asia Tenggara dijadikan sebagai target operasi pembajakan. Selat Malaka adalah tempat pembajakan paling berbahaya di Asia Tenggara. Terdapat sejumlah tragedi pembajakan yang terjadi setiap tahun, karena selat ini merupakan wilayah sepertiga aktivitas perdagangan dunia dilakukan dan dilalui oleh ribuan kapal setiap tahunnya. Makalah ini ingin menjawab bagaimana kerjasama keamanan maritim ASEAN memerangi pembajakan di Selat Malaka dengan melibatkan proses sosialisasi dan persuasi. Makalah ini bertujuan untuk mengeksplorasi kerjasama keamanan maritim ASEAN dalam memerangi pembajakan di Selat Malaka, serta membahas proses lengkap terkait interaksi, mekanisme dan kerangka kerja. Makalah ini juga akan membahas tentang peluang aktor luar di ASEAN, dalam menjalankan kepentingan mereka dalam kerjasama keamanan maritim ASEAN. Makalah ini menggunakan teori sosialisasi dan persuasi yang diprakarsai oleh Johnston Checkel, atau dengan kata lain teori mikro dari teori konstruktivisme untuk menghubungkan kerjasama keamanan maritim ASEAN di Selat Malaka dan prosesnya dalam memerangi pembajakan.
\end{abstract}

Keywords: ASEAN, Keamanan, Maritim, Pembajakan, Regionalisme

\section{Introduction}

Southeast Asia is a region which most countries inside it are archipelagic countries. ASEAN countries have large water territory which become the source of economic income but at the same time becoming threat for the national security. The problem which is currently faced by ASEAN countries is piracy. Most of the people in this world only know that piracy only happens in Somalia. Surprisingly, piracy also happens in ASEAN especially in Malacca Strait. This piracy disturbs the economic activities and security condition of countries border. Before the creation of ASEAN Political Security Community, there was a lack of joint-cooperation and patrol around a sea. Moreover, there was no specific mechanism and framework to conduct operation to tackle piracy. Learning from the condition, elites in ASEAN are motivated to pin this one of the security issues as one of the important problem which is needed to be solved. 
The paper would like to answer how ASEAN maritime security cooperation combat piracy within Malacca Strait involving socialization and persuasion. Moreover, its purpose is to explore ASEAN maritime security cooperation to combat piracy within Malacca Strait and it's process complete with interaction, mechanism and framework. This paper would also like to discuss about the opportunity of extra-regional actor in exercising their interest in ASEAN maritime security cooperation. This paper uses theory of socialization and persuasion initiated by Johnston Checkel or the micro-theory of constructivism to link ASEAN maritime security cooperation to combat piracy within Malacca Strait and its process. This paper will be divided into four parts; introduction, theoretical framework, analysis, and conclusion. The reason why this paper discusses about this topic is because it is rarely discussed as paper or forum and there is unique fact about piracy in Malacca Strait which can be explored throughout this paper. The paper affirms that during the process of formulating ASEAN maritime security cooperation to combat piracy within Malacca Strait, it involved process of socialization by adopting norms, values, attitudes and behaviors which were accepted and practiced by ongoing systems and there is successful persuasion which is shown by the homogenization of interests and shares of cooperative interests between ASEAN member countries.

ASEAN is a regional organization in Southeast Asia which were established on August $8^{\text {th }}, 1967$ through Bangkok Declaration. ${ }^{1}$ Maritime is a place near the sea. ${ }^{2}$ Piracy is crime of attacking ships and stealing from them. ${ }^{3}$ Security is measures to protect a country, building or person against attack, danger. ${ }^{4}$

\section{Theoretical Framework}

The paper uses theory of socialization and persuasion theory which was initiated by Johnston Checkel. There is socialization through principled ideas and institutions. ${ }^{5}$ For this paper, the socialization will be narrowed to the political socialization which defined by Siegal as process by which people learn to adopt the norms, values, attitudes and behaviors which

\footnotetext{
${ }^{1}$ ASEAN, “Overview," ASEAN, http://asean.org/asean/about-asean/overview/ (retrieved on October 29" 2018)

${ }^{2}$ Oxford Learner Dictionary, "Fourth Edition." 269.

${ }^{3}$ Ibid., 333.

${ }^{4}$ Ibid., 397.

5 Amitav Archarya, "Theoretical Perspectives on International Relations in Asia," 4, October 29th 2018, http://www.amitavacharya.com/sites/default/files/Theoretical\%20Perspectives\%20on\%20International\%20Relat ions\%20in\%20Asia.pdf
} 
accepted and practiced by the ongoing system. ${ }^{6}$ Socialization also is a process resulting in internalization of norms in which the issue will be assumed as taken for granted. ${ }^{7}$ For the persuasion, it is the process which involves changing minds, opinions and attitude about causality and affect which can lead to the creation of common knowledge or homogenization of interest. ${ }^{8}$ Actors which are persuaded can share their cooperative interests. ${ }^{9}$

\section{Analysis}

Malacca Strait is located between Indonesia, Malaysia and Singapore which become international shipping superhighways. ${ }^{10}$ This strait is 550 miles long and 1.7 miles wide. ${ }^{11}$ Annually, about 120,000 ships passed this way which equal with third of world's marine commerce. ${ }^{12}$ About 70 percent to 80 percent of oil imported by China and Japan passed the straits. ${ }^{13}$ Based on report from International Chamber of Commerce (ICC) and International Maritime Bureau (IMB), the frequency of piracy happened every two weeks and they usually hijack small coastal tanker. ${ }^{14}$ The piracy was performed by armed gangs with the goal of stealing fuel. ${ }^{15}$ From all this fact, it can be inferred that number of piracy in Malacca Strait surpasses number of piracy in Somalia because in 2015 IMB Report, there was zero piracy in Somalia. ${ }^{16}$

Seeing that this problem threatened the economic activity as well as territorial border of ASEAN member states, the elites motivated to pin this issue into important agenda in ASEAN Political Security Community. The ASEAN Way such as principle of consensus, dialogue, consultation and non-interference became the foundation of the creation of

\footnotetext{
${ }^{6}$ Alastair Iain Johnston, "Treating International Institutions as Social Environments," International Studies Quarterly 45 (2001): 494-495, retrieved on October $29^{\text {th }} 2018$, https://pdfs.semanticscholar.org/8519/54244883515f13e01e432a2c7d6a6eb012ec.pdf

${ }^{7}$ Ibid., 495.

${ }^{8}$ Ibid.

${ }^{9}$ Ibid.

${ }^{10}$ Adam McCauley, "The Most Dangerous Waters in the World," TIME, http://time.com/piracy-southeast-asiamalacca-strait/ (retrieved on October $29^{\text {th }} 2018$ )

${ }^{11}$ Joyce Dela Pena, "Maritime Crime in the Strait of Malacca: balancing Regional and Extra-Regional Concerns," Stanford Journal of International Relations Vol.X, no 2 (2009): 2, retrieved on October 29 ${ }^{\text {th }} 2018$, https://web.stanford.edu/group/sjir/pdf/Pirates.pdf

${ }^{12}$ Adam McCauley, "The Most Dangerous Waters in the World," TIME, http://time.com/piracy-southeast-asiamalacca-strait/ (retrieved October $29^{\text {th }} 2018$ )

${ }^{13} \mathrm{Ibid}$.

${ }^{14}$ Laura Southgate, "Piracy in the Malacca Strait: Can ASEAN Respond?," The Diplomat, July $8^{\text {th }} 2015$, https://thediplomat.com/2015/07/piracy-in-the-malacca-strait-can-asean-respond/ (retrieved on October $29^{\text {th }}$ 2018)

${ }^{15} \mathrm{Ibid}$

${ }^{16}$ Ibid.
} 
mechanism, institution and framework which facilitate the maritime security cooperation to combat piracy in Malacca Strait. Before the creation of ASEAN Political Security Community, the elites already created ASEAN Regional Forum (ARF) on July $25^{\text {th }} 1993 .{ }^{17}$ The purpose of this forum is to facilitate dialogue and consultation on security issues as well as common interest. ${ }^{18}$ The ASEAN Regional Forum in their Statement on Cooperation Against Piracy and Other Threats to Security explicitly stated in the first point of statement that they recognize piracy and armed robbery against ships threaten growth of Asia Pacific region and disrupt stability of global commerce. ${ }^{19}$ In the third point, they pointed out that maritime security is indispensable and it becomes fundamental condition for welfare and economic security of ASEAN Regional Forum countries. ${ }^{20}$ This point reflects how concerning piracy is in their maritime security agenda because they already recognized about the negative implication and consequences about piracy within the region. Moreover, there are numerous actions which were established by ASEAN to combat piracy such as Work Program to Implement ASEAN Plan of Action to Combat Transnational Crime. ${ }^{21}$ There is also ADMM Logistics Support Framework. ${ }^{22}$ Likewise, ARF conducted workshop and seminars about capacity building. ${ }^{23}$

After the establishment of ARF, when ASEAN Political Security Community still in form of Plan of Action, there was the establishment of ASEAN Defense Ministers Meeting (ADMM) on May $9^{\text {th }} 2006$ which purpose is to facilitate defense consultation and cooperation mechanism. ${ }^{24}$ Then, in 2009 the ASEAN Political Security Community Blueprint 2015 passed. In APSC Blueprint 2015, piracy included in point B.4 about non-traditional security issues and explicitly stated in point number B.4.1 about strengthening cooperation in

\footnotetext{
${ }^{17}$ ASEAN Regional Forum, “About The ASEAN Regional Forum," ASEAN Regional Forum, http://aseanregionalforum.asean.org/about.html (retrieved on October $29^{\text {th }} 2018$ )

${ }^{18}$ Ibid.

${ }^{19}$ ASEAN, “ARF Statement on Cooperation Against Piracy and Other Threats to Security," ASEAN, June $17^{\text {th }}$ 2003, http://asean.org/arf-statement-on-cooperation-against-piracy-and-other-threats-to-security/ (retrieved on October $29^{\text {th }} 2018$ )

${ }^{20}$ Ibid.

${ }^{21}$ ASEAN, "Work Programme to Implement the ASEAN Plan of Action to Combat Transnational Crime," $A S E A N$, July $4^{\text {th }} 2012$, http://asean.org/?static_post=work-programme-to-implement-the-asean-plan-of-actionto-combat-transnational-crime-kuala-lumpur-17-may-2002 (retrieved on October $29^{\text {th }} 2018$ )

${ }^{22}$ ASEAN, "Joint Declaration of the ASEAN Defence Ministers on Partnering for Change, Engaging the World," ASEAN, http://asean.org/storage/2017/10/11th-ADMM-Joint-Declaration-as-of-23-Oct-20172.pdf (retrieved on October $29^{\text {th }} 2018$ )

${ }^{23}$ Maritime Institute of Malaysia, ASEAN Regional Forum Workshop on Capacity Building of Maritime Security, No. 9, 2004, http://www.asean.org/uploads/archive/arf/13ARF/ws-capacity-building/annex\%206.pdf (retrieved on October $29^{\text {th }}$ 2018)

${ }^{24}$ ASEAN Defence Ministers' Meeting, “About ASEAN Defence Ministers' Meeting (ADMM),” ADMM, https://admm.asean.org/index.php/about-admm/about-admm.html (retrieved on October 29 ${ }^{\text {th }} 2018$ )
} 
addressing non-traditional security issues specifically in actions number xvii stated that forge closer cooperation in fighting against sea piracy and armed robbery against ships. ${ }^{25}$ In APSC Blueprint 2025, piracy explicitly stated in point B.6.2 regarding promoting maritime cooperation to address maritime issues, specifically in actions number $\mathrm{v}$ stated that they promote linkages between national, regional and international mechanism on maritime cooperation such as piracy and armed robbery against ships and actions number vii stated that they expand ASEAN maritime cooperation to effectively combat transnational crimes such as piracy. ${ }^{26}$ Other point which is not discussed in this paper also provide instruction, actions and mechanism about ASEAN maritime security cooperation. Broader mechanism and specific actions are discussed in ASEAN Political Security Community Blueprint 2025 regarding combating piracy. The APSC Blueprint reflect that ASEAN elites perceived piracy as important security issues within ASEAN and it needs to be tackled seriously by specific mechanism and relevant actions.

If we analyze and correlate with theory, we could infer that there was a political socialization process where ASEAN elites learn to adopt norms and values of ASEAN then they began to accept it and practiced by the ongoing system. When they accept attitudes, it means they knew that there are number of piracies happened but there is still lack of relevant mechanism and framework to conduct joint-cooperation within ASEAN. They internalized the norms and issue of maritime security such as piracy, assumed as taken for granted and it became the important issue among member countries. There was a persuasion process where ASEAN elites changes their minds, opinions and attitudes towards non-traditional security issues especially piracy, because they knew about the causality of piracy and the consequences of piracy towards region's growth and economic. There was a common knowledge that ASEAN members mostly realized that piracy mostly happened within ASEAN waters and it will be continued as significant threat within the region (RSIS). This led to the homogenization of interest and share of cooperative interest which reflected in ASEAN Regional Forum, ASEAN Political Security Community Blueprint, ASEAN Maritime Forum, Maritime Security Expert Working Group (MSEWG), ARF Statement on

\footnotetext{
25 ASEAN Secretariat, ASEAN Political Security Community Blueprint 2015 (Jakarta: ASEAN Secretariat, 2009), http://www.asean.org/storage/images/archive/22337.pdf

${ }^{26}$ ASEAN Secretariat, ASEAN Political Security Community Blueprint 2025 (Jakarta: ASEAN Secretariat, 2016), http://www.asean.org/storage/2012/05/ASEAN-APSC-Blueprint-2025.pdf
} 
Cooperation against Piracy and ASEAN Defense Ministers Meeting (ADMM), ARF Capacity Building, ARF Seminar and Field Training.

The momentum in conducting maritime security cooperation, especially in tackling piracy within Malacca Strait considered as opportunity for extra-regional actors to exercise their interest in ASEAN. Countries such as United States, Japan, and China have interest in combating piracy within Malacca Strait. ${ }^{27}$ For United States, the reason why they were having interest is because they wanted to prevent maritime terrorism within Malacca Straits. ${ }^{28}$ For China, they were having interest to combat this issue, because their economic income mostly come from maritime commerce and oil imports. ${ }^{29}$ The Malacca Strait reflect how important strait security for China's economic growth. ${ }^{30}$ For Japan, they were having interest because like China, Japan's oil import up to 70 percent pass the strait. ${ }^{31}$ Japan also concerned about vulnerability of shipping, growing maritime threat, sustaining freedom of ocean and ruled-based order at sea which in line with United National Convention on the Law of Sea (UNCLOS). ${ }^{32}$

For India, their interest revolves from the history of Indian traders from port of Mahabalipuram voyage to Eastern parts of Indo-China through Malacca Straits. ${ }^{33}$ Since long time ago, Malacca Straits had high priority in Indian interaction with Southeast Asian states and continued with empire of Srivijaya. ${ }^{34}$ Because 46 percent of India's trade passing Malacca Strait, it is necessary for India to ensure safe of shipping. ${ }^{35}$ European Union also has its own interest in having security cooperation in Malacca Straits. ${ }^{36}$ The reason is because

\footnotetext{
27 Joyce Dela Pena, "Maritime Crime in the Strait of Malacca: balancing Regional and Extra-Regional Concerns," Stanford Journal of International Relations Vol.X, no 2 (2009): 2, retrieved on October 29 2018 , https://web.stanford.edu/group/sjir/pdf/Pirates.pdf

${ }^{28}$ Ibid., 5.

${ }^{29}$ Ibid.

${ }^{30}$ Ibid.

${ }^{31}$ Ibid.

${ }^{32}$ Nguyen Hung Son, “ASEAN-Japan Strategic Partnership in Southeast Asia: Maritime Security and Cooperation,” http://www.jcie.org/japan/j/pdf/pub/publst/1451/12_nguyen.pdf (retrieved on October 29 ${ }^{\text {th }} 2018$ ) 220.

${ }^{33}$ Vijay Sakhuja, "Cooperative Security in the Straits of Malacca: Policy Options for India," Observer Research Foundation, June $15^{\text {th }} 2005$, https://www.orfonline.org/research/cooperative-security-in-the-straits-of-malaccapolicy-options-for-india/ (retrieved on October $29^{\text {th }} 2018$ )

${ }^{34}$ Ibid.

${ }^{35}$ Ibid.

${ }^{36}$ Heather Gilmartin, "EU-U.S.-China: Cooperation in the Malacca Straits," INSTITUT FÜR FRIEDENSFORSCHUNG UND SICHERHEITSPOLITIK an der Universität Hamburg, (2008): 18-19, retrieved on October 29 ${ }^{\text {th }} 2018$, https://www.files.ethz.ch/isn/94660/hb151.pdf
} 
almost EU trade passes the Straits especially trade with China and East Asia. Moreover, their interest also driven by investment of European within the region. There are various programs proposed by extra-regional actors in combating piracy within Malacca Strait with ASEAN member countries such as the Regional Maritime Security Initiative (RMSI) and Proliferation Security Initiative (PSI) proposed by United States. ${ }^{37}$ Moreover, Japan proposed the formation of joint patrols which consist of Japan, South Korea, China, Malaysia, Indonesia and Singapore. ${ }^{38}$ Japan also proposed their major initiative which is Regional Cooperation Agreement on Combating Piracy and Armed Robbery Against Ships in Asia (ReCAAP) in $2006 .{ }^{39}$ India proposed joint naval patrol with United States. ${ }^{40}$ Likewise, India proposed bilateral naval cooperation, naval exercises, operating procedures, and cooperative security framework. ${ }^{41}$ Unfortunately, almost all programs proposed by extra-regional actors rejected by Malaysia, Indonesia and Singapore. They wanted to prevent foreign intervention for this issue. $^{42}$ They expressed that they are sensitive toward the deployment of outside powers in Malacca Straits. ${ }^{43}$ They pointed out that foreign forces would not capable in understanding local knowledge and local culture to deal with the threat. ${ }^{44}$ The characteristic of United States post-colonial such as economic control and antagonism contribute to the reluctance of littoral state to accept the proposed programs. ${ }^{45}$

\footnotetext{
${ }^{37}$ Joyce Dela Pena, "Maritime Crime in the Strait of Malacca: balancing Regional and Extra-Regional Concerns," Stanford Journal of International Relations Vol.X, no 2 (2009): 5, retrieved on October 29 2018 , https://web.stanford.edu/group/sjir/pdf/Pirates.pdf

38 Ibid., 6.

${ }^{39}$ Nguyen Hung Son, "ASEAN-Japan Strategic Partnership in Southeast Asia: Maritime Security and Cooperation," http://www.jcie.org/japan/j/pdf/pub/publst/1451/12_nguyen.pdf (retrieved on October 29 ${ }^{\text {th }} 2018$ ) 221.

${ }^{40}$ Vijay Sakhuja, "Cooperative Security in the Straits of Malacca: Policy Options for India," Observer Research Foundation, June $15^{\text {th }} 2005$, https://www.orfonline.org/research/cooperative-security-in-the-straits-of-malaccapolicy-options-for-india/ (retrieved on October $29^{\text {th }} 2018$ )

${ }^{41}$ Ibid.

${ }^{42}$ Joyce Dela Pena, "Maritime Crime in the Strait of Malacca: balancing Regional and Extra-Regional Concerns," Stanford Journal of International Relations Vol.X, no 2 (2009): 7, retrieved October 29 2018 , https://web.stanford.edu/group/sjir/pdf/Pirates.pdf

${ }^{43}$ Mushahid Ali \& Jeffrey Chen, "Maritime Security Cooperation in the Malacca Straits: Prospects and Limits," $R S I S$, July $1^{\text {st }} 2004$, https://www.rsis.edu.sg/rsis-publication/rsis/619-maritime-securitycooperation/\#.WuchzHdh3-Z (retrieved on October $29^{\text {th }} 2018$ )

${ }^{44}$ Ibid.

${ }^{45}$ Joyce Dela Pena, "Maritime Crime in the Strait of Malacca: balancing Regional and Extra-Regional Concerns," Stanford Journal of International Relations Vol.X, no 2 (2009): 6, retrieved on October 29 2018 , https://web.stanford.edu/group/sjir/pdf/Pirates.pdf
} 
ASEAN Way such as consultation and non-interference is needed. ${ }^{46}$ To accept extraregional actors, the littoral states need to be comfortable first with the working atmosphere as the first step to accept the presence of extra-regional actors. ${ }^{47}$ The littoral states did not want to be driven by extra-regional actors, but they want to drive the cooperation. ${ }^{48}$ The littoral states only want the extra-regional actors as assistance donor but with note that they only want to accept the assistance as long as the assistance is neutral, limited and non-military. ${ }^{49}$ The littoral states itself has already launched joint-cooperation such as Malacca Straits Patrol MALSINDO but with respect of sovereignty, the patrols are not allowed to enter territorial water of another state. ${ }^{50}$ There is also aerial patrol called Eyes in the Sky travel up to three nautical miles. ${ }^{51}$

The unique fact about piracy in Malacca Strait is the number of piracy incident in Malacca Strait surpasses number of piracy in Somalia and West Africa. Sometimes, the armed gangs which ride a boat in Malacca Strait cannot be detected because they misuse another country flag to deceive the security personnel. ${ }^{52}$ Based on Peter Chalk, researcher at Rand Corp think tank, said that the system of use of flag is different because when the ship is owned by Japan, surprisingly it can be sailed by different flag but using different captain with different crew. ${ }^{53}$ The hijacker in Malacca Strait indicated that either they have direct link or network with the crew on board or they have knowledge about ship and cargo. ${ }^{54}$ Because most of the piracy in Malacca Strait attempted to steal oil, the hijacker surely have link with a person who have oil-industry experience because they need to mix oil and siphon the liquid. ${ }^{55}$

\footnotetext{
${ }^{46}$ Mushahid Ali \& Jeffrey Chen, "Maritime Security Cooperation in the Malacca Straits: Prospects and Limits," $R S I S$, July $1^{\text {st }} 2004$, https://www.rsis.edu.sg/rsis-publication/rsis/619-maritime-securitycooperation/\#.WuchzHdh3-Z (retrieved on October $29^{\text {th }} 2018$ )

47 Ibid.

48 Ibid.

${ }^{49}$ Joyce Dela Pena, "Maritime Crime in the Strait of Malacca: balancing Regional and Extra-Regional Concerns," Stanford Journal of International Relations Vol.X, no 2 (2009): 7, retrieved on October 29 ${ }^{\text {th }} 2018$, https://web.stanford.edu/group/sjir/pdf/Pirates.pdf

${ }^{50}$ Laura Southgate, "Piracy in the Malacca Strait: Can ASEAN Respond?," The Diplomat, July $8^{\text {th }} 2015$, https://thediplomat.com/2015/07/piracy-in-the-malacca-strait-can-asean-respond/ (retrieved on October $29^{\text {th }}$ 2018)

${ }^{51}$ Ibid.

${ }^{52}$ Adam McCauley, "The Most Dangerous Waters in the World," TIME, http://time.com/piracy-southeast-asiamalacca-strait/ (retrieved October $29^{\text {th }} 2018$ )

${ }^{53} \mathrm{Ibid}$.

${ }^{54} \mathrm{Ibid}$.

${ }^{55}$ Ibid.
} 
In order the oil can be sold, they will mix pirated oil with crude sea oil and resold to the buyers who ignore the source of oil. ${ }^{56}$

\section{Conclusion}

In conclusion, there are many actions established by ASEAN and member states in combating piracy such as the establishment of ASEAN Political Security Community, ASEAN Regional Forum (ARF), ASEAN Regional Forum in their Statement on Cooperation Against Piracy and Other Threats to Security, Work Program to Implement ASEAN Plan of Action to Combat Transnational Crime, etc. From the analysis using theory of socialization and persuasion from Johnston Checkel, it's clear that there was a political socialization process where ASEAN elites learn to adopt norms and values of ASEAN and eventually began to accept and practice it. Moreover, there was a persuasion process towards nontraditional security issues especially piracy, creation of common knowledge, homogenization of interest and share of cooperative interest. There are countries which had interest in maritime security cooperation within Malacca Strait such as United States, China, European Union, India, and Japan. They proposed various programs but some of them were rejected by littoral states due to the non-interference and consultation norms. Because the piracy targeted to steal oil from ships, the actor of piracy in Malacca Straits indicated that they have link with the crew on board and person experience with oil industry in order to sell it.

56 Ibid. 


\section{Bibliography}

ASEAN. n.d. Overview. Accessed October 29, 2018. http://asean.org/asean/aboutasean/overview/ .

Bull, Victoria. n.d. Oxford Learner Dictionary: Fourth Edition. Oxford: Oxford University Press.

Archarya, Amitav. n.d. Theoretical Perspectives on International Relations in Asia.

Johnston, Alastair Iain. 2001. " Treating International Institutions as Social Environments." International Studies Quarterly 45: 494-495.

McCauley, Adam. n.d. The Most Dangerous Waters in the World. Accessed October 29, 2018. http://time.com/piracy-southeast-asia-malacca-strait/ .

Dela Pena, Joyce. 2009. "Maritime Crime in the Strait of Malacca: balancing Regional and Extra-Regional Concerns." Stanford Journal of International Relations (Stanford University) X: 2.

Southgate, Laura. 2015. Piracy in the Malacca Strait: Can ASEAN Respond? July 8. Accessed October 29, 2018. https://thediplomat.com/2015/07/piracy-in-the-malaccastrait-can-asean-respond/.

ASEAN Regional Forum. n.d. About The ASEAN Regional Forum. Accessed October 29, 2018. http://aseanregionalforum.asean.org/about.html .

ASEAN. 2003. ARF Statement on Cooperation Against Piracy and Other Threats to Security. June 17. Accessed October 29, 2018. http://asean.org/arf-statement-on-cooperationagainst-piracy-and-other-threats-to-security/ .

- 2012. Work Programme to Implement the ASEAN Plan of Action to Combat Transnational Crime. July 4. Accessed October 29, 2018. http://asean.org/?static_post=work-programme-to-implement-the-asean-plan-ofaction-to-combat-transnational-crime-kuala-lumpur-17-may-2002 .

Maritime Institute of Malaysia. 2004. ASEAN Regional Forum Workshop on Capacity Building of Maritime Security. ASEAN.

ASEAN Defence Ministers' Meeting. n.d. About ASEAN Defence Ministers' Meeting $(A D M M)$. Accessed October 29, 2018. https://admm.asean.org/index.php/aboutadmm/about-admm.html .

ASEAN Secretariat. 2009. ASEAN Political Security Community Blueprint 2015 . Jakarta, DKI Jakarta: ASEAN Secretariat.

ASEAN Secretariat. 2016. ASEAN Political Security Community Blueprint 2025 . Jakarta, DKI Jakarta: ASEAN Secretariat.

Hung Son, Nguyen. n.d. ASEAN-Japan Strategic Partnership in Southeast Asia: Maritime Security and Cooperation. Japan Centre for International Exchange. 
Sakhuja, Vijay. 2005. Cooperative Security in the Straits of Malacca: Policy Options for India. June 15. Accessed October 29, 2018.

https://www.orfonline.org/research/cooperative-security-in-the-straits-of-malaccapolicy-options-for-india/ .

Gilmartin, Heather. 2008. EU-U.S.-China: Cooperation in the Malacca Straits. INSTITUT FÜR FRIEDENSFORSCHUNG UND SICHERHEITSPOLITIK an der Universität Hamburg.

Chen, Mushahid Ali \& Jeffrey. 2004. Maritime Security Cooperation in the Malacca Straits: Prospects and Limits. July 1. Accessed October 29, 2018.

https://www.rsis.edu.sg/rsis-publication/rsis/619-maritime-securitycooperation/\#.WuchzHdh3-Z .

ASEAN. 2017. "Joint Declaration of the ASEAN Defence Ministers on Partnering for Change, Engaging the World." ASEAN. October 23. Accessed October 29, 2018. http://asean.org/storage/2017/10/11th-ADMM-Joint-Declaration-as-of-23-Oct20172.pdf. 